\title{
On gonads and gadflies: the estrus angle
}

\section{Stephen G Hillier}

Medical Research Council Centre for Reproductive Health, University of Edinburgh, Queen's Medical Research Institute, Edinburgh, United Kingdom
Correspondence should be addressed to S G Hillier

Email

steve.hillier@ed.ac.uk

\begin{abstract}
The first sex steroid to be crystallized was the vertebrate ovarian hormone, estrone - a less potent metabolite of $17 \beta$-estradiol, which in mammals stimulates the female urge to mate (estrus). The gadfly (Greek oistros) lent its name to the process of estrus, as an insect that bites and torments in classical Greek mythology. With the purification and crystallization of a moult-inducing steroid (ecdysone) from insects, an interesting parallel emerged between mating and moulting in lower mammals and arthropods. Ecdysterone (potent ecdysone metabolite) has anabolic effects in mammalian muscle cells that can be blocked by selective estrogen receptor antagonists. Insects utilize ecdysteroids in similar ways that vertebrates use estrogens, including stimulation of oocyte growth and maturation. Ecdysteroids also modify precopulatory insect mating behaviour, further reinforcing the gonad-gadfly/mate-moult analogy.
\end{abstract} Key Words

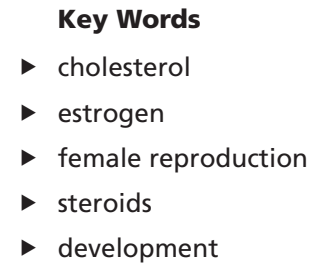

Journal of Endocrinology (2017) 233, C1-C8

\section{Introduction}

'In the Lucanian woods among the oaks

Of green Alburnus' slopes there swarms a fly

(By us called gadfly, oestrus by the Greeks).

It's fierce and buzzes monstrously: whole herds

In terror of it scatter through the woods,

Until the sky rings with their bellowing...'

Virgil, The Georgics, Book III (Mackenzie 1969)

Virgil's description of demented cattle shrouded in clouds of stinging gadflies provides a striking metaphor for hormone-induced sexual arousal and unwittingly links steroid signaling in mammals and insects. The Victorian reproductive biologist Walter Heape (Heape 1900) seized upon Virgil's verse to bring forward the concept of the 'estrous' cycle (Box 1) in which a female's period of heightened sexual receptivity to the male is termed estrus (Greek oistros 'gadfly, breeze, sting, mad impulse'). Crystallization of an estrus-inducing steroid (eventually named estrone) from the urine of pregnant women founded the sex hormone era and effectively launched the clinical specialism of reproductive medicine. Decades on, a moult-inducing steroid that controls ecdysis (Greek $e k d u o$ 'to take off, strip off') in insects - including gadflies - would be crystallized from silk-moth pupae and named ecdysone (Karlson 1996).

This commentary draws attention to the equivalence of estrus and ecdysis as fundamental reproductive events and celebrates the enduring impact of the sex steroids that control them. It also marks the centenary of the classic estrogen bioassay: the vaginal smear test for estrus (Stockard \& Papanicolaou 1917), which was instrumental to the discovery of estrone.

\section{Essence of estrus}

A defining moment in steroid endocrinology was the announcement that surgical removal of the ovaries from adult female rabbits caused uterine atrophy, which could be prevented by auto-transplantation of ovarian fragments

Published by Bioscientifica Ltd. 
Box 1: The estrous cycle of lower mammals (Heape 1900).

1. Pro-estrus: The period of 'coming on heat' or 'coming in season', when the generative organs become hyperthrophied and congested.

2. Estrus: The period of heightened sexual arousal and activity; desire for coition.

3. Metestrus: When, in the absence of the male, the desire for coition gradually dies away.

4. Diestrus or anestrus: The rest interval between recurrent cycles or breeding seasons.

to ectopic sites in the abdominal cavity (Knauer 1900). This classic ablation-replacement experiment started the hunt that resulted in the discovery of the first female sex steroid a quarter of a century later.

Allen \& Doisy (1924) proved the existence of an estrus-inducing substance in the ovary by injecting fresh porcine follicular fluid or ovarian extracts into ovariectomized rats. Estrus was detected as cornification of the vaginal epithelium, observed by microscopic examination of vaginal smears. This simple test for estrus, introduced by Stockard \& Papanicolaou (1917), was instrumental in the eventual isolation of a pure estrogen: 'The clear-cut nature of this test lessens the confusion of uncertain results. This improvement in testing has enabled us to make more than 600 separate tests of extracts in a little over 1 year...' (Allen \& Doisy 1924).

The first estrus-producing hormone to be crystallized was estrone (Butenandt 1929, Doisy et al. 1929, 1930), quickly followed by estriol (Marrian 1930) - both from human pregnancy urine. In the event, estrone and estriol proved to be weak metabolites of $17 \beta$-estradiol (estradiol), which is the major estrogen secreted by the ovary (Simpson \& Santen 2015). Estradiol itself was purified (from porcine ovarian follicular fluid) five years later (MacCorquodale et al. 1936). However, without question, it was the initial isolation of crystalline estrone that launched the sex hormone era.

\section{What's in a name?}

The naming of estrone is a story in its own right (Corner 1964). Doisy suggested 'theelin', derived from the Greek thelys, meaning 'female' (Veler etal. 1930). Others suggestions included 'folliculine' (Courrier 1924), 'menoformon' (Laquer et al. 1930) and 'progynon' (Butenandt 1932). Parkes \& Bellerby (1926), harking back to Virgil, proposed 'oestrin' explicitly to accommodate the compound's estrusproducing property. Oestrin would eventually morph into estrone, providing the etymological stem for a generation of natural and synthetic estrus-producing steroids that were about to be discovered and synthesized (Doisy 1941).

\section{Cholesterol connections}

The basic chemistry of the sterol/steroid ring system was solved for cholesterol in 1932 (Bloch 1982). Along the way, Heinrich Wieland was awarded the 1927 Nobel Prize in Chemistry for '...investigations of the constitution of the bile acids and related substances', and the 1928 Nobel Prize in Chemistry was awarded to Adolf Windaus for 'research into the constitution of the sterols and their connection with the vitamins'. Adolf Butenandt, who had been Windaus' graduate student, was therefore ideally placed to deduce the chemical constitution of the estrusinducing steroid (Butenandt 1932) (Fig. 1).

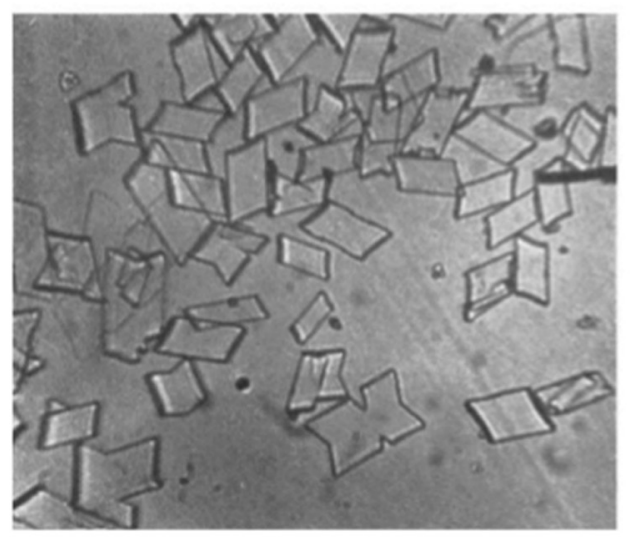

Estrone crystals. Magnification $\times 416$
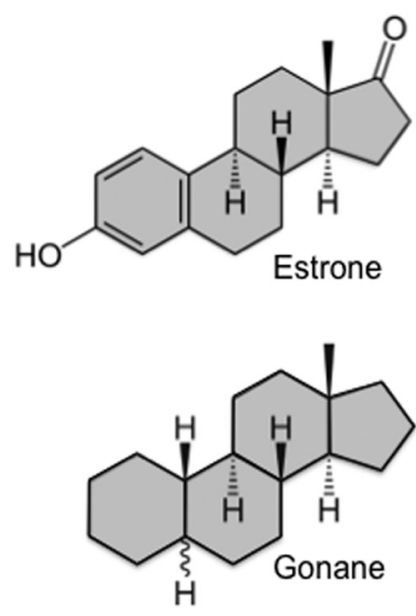

\section{Figure 1}

Pure estrone. (left) Platelet crystals of estrone. Reproduced, with permission, from EA Doisy, CD Veler \& S Thayer (1930) The preparation of the crystalline ovarian hormone from the urine of pregnant women, Journal of Biological Chemistry, volume 86, pages 499-509. Copyright 1930, the American Society for Biochemistry and Molecular Biology. (top right) Estrone steroidal structure. (bottom right) Gonane, the nuclear hydrocarbon structure upon which the systematic nomenclature of all natural and synthetic steroidal substances is based. 
A consensus nomenclature for steroidal estrogens quickly emerged, based on the carbon atom numbering system already used for C27-cholesterol. In this system, the parent C18 molecule was termed 'estrane', i.e. the core fourring gonane skeleton with one methyl group and minus the cholesterol side chain (Adam et al. 1933; Fig. 1). Thus, when the parent estrus-inducing steroid was eventually obtained (MacCorquodale et al. 1936), a systematic nomenclature was already available to accommodate it as estradiol.

\section{Raging hormones}

Intense interest in estrogens and their therapeutic potential heralded the 'decade of the sex hormones', in which all the major mammalian sex steroids were sourced, purified and crystallized. Adolph Butenandt - arguably the steroid chemist of his century - was involved throughout. On the androgen front, Butenandt \& Tschering (1934) isolated $15 \mathrm{mg}$ of a hormonal substance they named androsterone from 15,000 liters of male urine. Androsterone proved to be a weak metabolite of the main testicular androgen, testosterone, which was isolated from bull testes by Ernst Lacquer (David et al. 1935) and simultaneously synthesized by Ruzicka \& Wettstein (1935). Butenandt \& Westphal (1935) also achieved isolation of the 'second' female sex steroid, progesterone - the hormone of pregnancy - from pig ovaries. So in the space of five years, Butenandt had contributed to the discovery of all three major sex hormones, for which he and Ruzicka shared the 1939 Nobel Prize in Chemistry. There was more to come.

\section{The gonane guarantee}

By 1936, the sex steroid pantheon - estradiol, testosterone and progesterone - was complete, and the term 'steroid' (sterol-like) was coined: 'for the group of compounds comprising the sterols, bile acids, heart poisons, saponins and sex hormones'. All distinguished by the trademark gonane motif (Callow \& Young 1936).

But other nuggets remained to be mined. Not least cortisone, which was crystallized independently by Edward Kendal (Mason et al. 1936) and Tadeus Reichstein (Reichstein 1936) from bovine adrenal glands. Dubbed 'the hormone of life', the anti-inflammatory properties of cortisone made it one of the wonder drugs of the 20th century (Hillier 2007). Aldosterone, the salt-conserving adrenal steroid, would follow nearly two decades later (Simpson et al. 1953), almost coincident with the discovery of ecdysone (see below).

After a hiatus during World War II, there was an explosion of interest in steroid chemistry and pharmaceutics. With the discovery of sex steroids and cortisone, the race was on to synthesize more and more steroid analogues with beneficial therapeutic effects. By 1956, the number of known steroidal substances was listed at around 7000 (Klyne 1957).

Application of X-ray crystallography to resolve steroid structures confirmed the canonical, four-ring nuclear structure of cholesterol that had been deduced by the early steroiders and underscored the boundless potential of 3D steroidal signaling (Carlisle \& Crowfoot 1945) (Fig. 2).

\section{Butenandt's butterflies}

The ubiquity of steroids and their critical importance to plant and animal life were becoming increasingly clear. Not yet appreciated was that members of the most abundant animal phylum on earth - the arthropods - have a customized sex steroid signaling system, seemingly based on a prototypic sex steroid that acquired control over moulting and metamorphosis during evolution (De Loof et al. 2016).

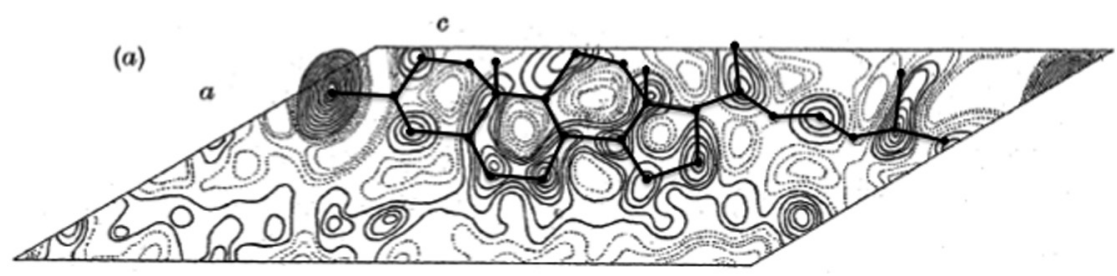

"I became captivated by the edifices chemists had raised through experiment and imagination - but still I had a lurking question. Would it not be better if one could really 'see' whether molecules as complicated as the sterols [...] were just as experiment suggested?"

Dorothy Crowfoot Hodgkin, Nobel Lecture, 1964

\section{Figure 2}

Crystal structure of cholesteryl iodide. X-ray diffraction analysis, showing an electron-density map with the tetracyclic gonane nucleus and alkyl side-chain contour drawn in. Adapted, with permission, from Carlisle CH \& Crowfoot D (1945) The crystal structure of cholesteryl iodide. Proceedings of the Royal Society of London: Series A, Mathematical and Physical Sciences, volume 184, pages 64-83. Quoted text reproduced from Hodgkin DC (1972) The X-ray analysis of complicated molecules. [Nobel Lecture, December 11, 1964]. In Nobel Lectures, Chemistry 1963-1970, 71-91. Amsterdam: Elsevier Publishing Co.
() 2017 Society for Endocrinology Printed in Great Britain 


\section{Box 2: The insect moult (Nijhout \& Callier 2015).}

1. Apolysis: Moulting hormones are pulsed into the haemolymph from the prothoracic gland and the old cuticle separates from the underlying epidermal cells.

2. Ecdysis: The old cuticle splits and is shed. The instar larva (progressive moult) or adult emerges, as its new cuticle is being synthesized.

3. Sclerotisation: The new cuticle hardens. At the final moult, the wings expand as haemolymph is forced into the wing veins.

All arthropod species moult (Chang \& Mykles 2011). It is a defining feature of animals with a rigid exoskeleton, which is split and shed to accommodate serial phases of growth and development (Nijhout \& Callier 2015) (Box 2). The process depends on moult-inducing steroids secreted by the prothoracic gland as metabolites of dietary cholesterol (Schwedes \& Carney 2012). The first moult-inducing steroid to be identified - ecdysone - was crystallized by none other than Adolf Butenandt (Butenandt \& Karlson 1954). Butenandt's partner in crystallizing ecdysone, Peter Karslon, recalls: 'We collected $500 \mathrm{~kg}$ of male pupae from which $5 \mathrm{~kg}$ of a concentrate were extracted. This was then further reduced, and finally we obtained $25 \mathrm{mg}$ of the crystalline hormone, a purification factor of 1:10,000,000 ... Thus, after 20 years, Butenandt was back to steroids.' (Fig. 3) (Karlson 1995).

Ecdysone is necessary and sufficient to stimulate all stages of the insect moult (Nijhout \& Callier 2015). Considering the evolutionary success of arthropods $(>1$ million species recorded), extending back to the Cambrian period (i.e. over $500 \mathrm{myr}$ ), ecdysone is probably the most widespread and influential steroid hormone on earth (Báthori et al. 2008).

\section{Beyond buzzy}

It took over a decade before the steroidal structure of ecdysone was deduced (Huber \& Hoppe 1965,
Karlson et al. 1965), when it also emerged that ecdysone is a steroidal prohormone. Hydroxylation at C20 is required to produce the active moult-inducing hormone, 20-hydroxyecdysone or ecdysterone in insects (King \& Siddall 1966, Kaplanis et al. 1969) and crustaceans (Horn et al. 1966) (Fig. 3).

Unexpectedly, ecdysterone and related 'ecdysones' were also shown to occur in various ferns and evergreen plants (Kaplanis et al. 1967). The most active compound (ponasterone A) in the leaves of the conifer Podocarpus nakaii Hay proved to be very close in structure and activity to ecdysterone (Nakanishi et al. 1966). Critically, the recovery of ecdysteroids from this plant was orders of magnitude higher than that from insect sources, prompting the authors to remark: 'The ready isolation of insect moulting hormones from plants, in contrast to the extremely poor yield from insects ... makes it possible to supply large amounts of active substances for biological testing'. This proved to be the case, as shown below.

Most plant species are now believed to contain ecdysteroids of one form or another, some at concentrations up to $3 \%$ of their dry weight (Laekeman \& Vlietinck 2013, www.ecdybase.org). They are normally present as a cocktail of substances in which ecdysterone is dominant. At the time of writing, well over 400 ecdysteroidal compounds have been detected in over 100 plant families (annual and perennial): ecdysterone being the most widespread (Tarkowská \& Strnad 2016).
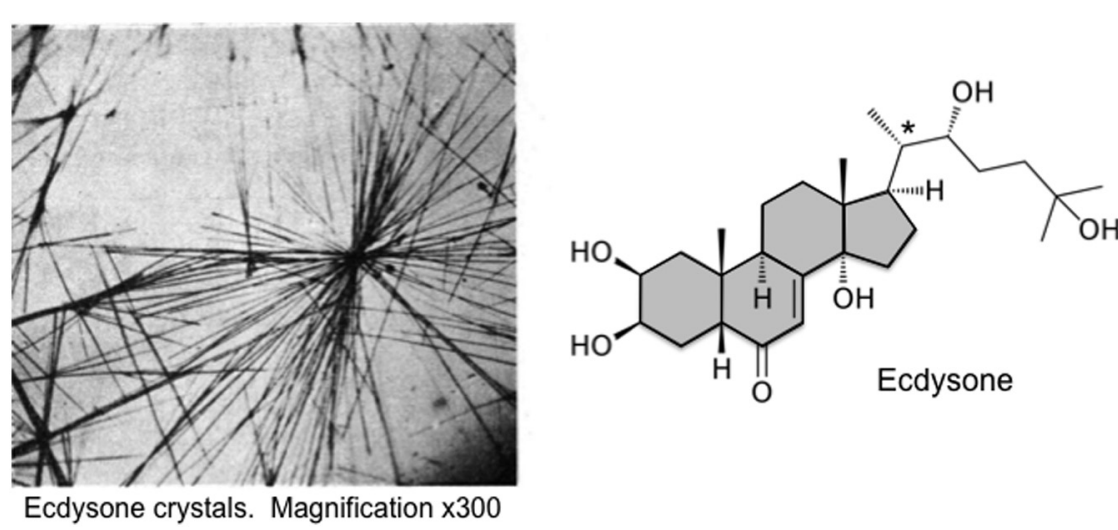

http://joe.endocrinology-journals.org DOI: 10.1530/JOE-17-0136

๑ 2017 Society for Endocrinology Printed in Great Britain

\section{Figure 3}

Moult-inducing steroids. (left) Crystals of ecdysone isolated from silk-moth pupae. Reproduced, with permission, from Butenandt A \& Karlson $\mathrm{P}$, 'Über die isolierung eines metamorphose-hormons der insekten in kristallisierter form'; in: Zeitschrift für Naturforschung B, vol 9 issue 6, Berlin: De Gruyter, 1954, pp. 389-391, fig. 3. (right) Steroid structure of ecdysone. Ecdysone is a prohormone for the more potent moult-inducing hormone 20-hydroxyecdysone (ecdysterone), which is formed by hydroxylation at C20 (asterisk). 


\section{Ecdysteroid anabolics}

A likely function of ecdysteroids in plants is to defend against insect and nematode infestation, through unbridled activation of ecdysteroid receptor (EcR) signaling (i.e. endocrine disruption) in the invader (Dinan 2009). Testing of plant-derived ecdysteroids in animal and human settings has revealed hepatoprotective, immunoprotective, antioxidant, hypoglycemic and anabolic properties, which have led to their use in dietary supplements and nutraceutical preparations. The anabolic potential of ecdysterone mainly rests on its ability to enhance physical performance associated with increased body mass in mice, as well as stimulation of protein synthesis in mouse and human skeletal muscle cells in vitro (Sláma \& Lafont 1995, Gorelick-Feldman et al. 2008). The mechanism of action includes binding and activation of estrogen receptor (ER) signaling. Selective ER antagonists block ecdysterone stimulated myotubular growth in vitro, and in silico molecular docking experiments support an ERß-mediated mode of ecdysterone action (Parr et al. 2014, 2015). Conversely, in silico studies imply estrogenic activation of EcR in arthropods (Swetha et al. 2016). The anabolic potential of ecdysterone as a dietary supplement in humans is such that it could yet be prohibited as a performance-enhancing drug by the World Anti-Doping Agency (Parr et al. 2015).

\section{Sex steroid surrogates}

Whether vertebrate-type sex steroids have physiological roles in insect reproduction is controversial (Swevers 1991, Das 2016, De Loof et al. 2016). On the other hand, insects evidently can use ecdysteroids in similar ways that vertebrates use estrogens, including e.g., stimulation of oocyte growth and maturation (De Loof 2006, De Loof et al. 2016). This is consistent with the widespread expression of EcR protein in adult insect tissues - including gonads and CNS (Schwedes \& Carney 2012) - and lack of an ER orthologue in the Drosophila genome (Boulanger \& Dura 2015). Estrogenic stimulation of oocyte growth and vitellogenesis in experimental crabs - also devoid of ER has been explained by estradiol binding to EcR, based on in silico ligand docking experiments (Swetha et al. 2016).

Insect precopulatory mating behaviour is also modified by ecdysteroids. The female fruit fly initially rejects potential suitors by various means, including full extrusion of her ovipositor to prevent copulation. But, as courtship proceeds, the ovipositor is partially withdrawn to signal increased receptiveness to the male. Ecdysteronedepleted female flies show reduced rejection behaviour in advance of copulation, which can be reversed by ecdysone feeding (Ganter et al. 2012). This implies a negative action of ecdysterone on female reproductive behaviour, the significance of which remains to be determined.

\section{A sting in the tail}

'See where she rages in Sila's woods,

A lovely heifer, while the rival bulls

Do mighty battle with alternate charge...'

Virgil, The Georgics, Book III (Mackenzie 1969)

Virgil's cattle were tormented by gadflies but might have bellowed for another reason.

The male's ambition and capacity to mate are driven by testicular androgens - principally testosterone. The urine and saliva of bulls and boars also contain high concentrations of odorous 16-androstane testosterone metabolites (Cox \& Turner 1984), which are implicated in the 'stink wars' between rutting males that compete

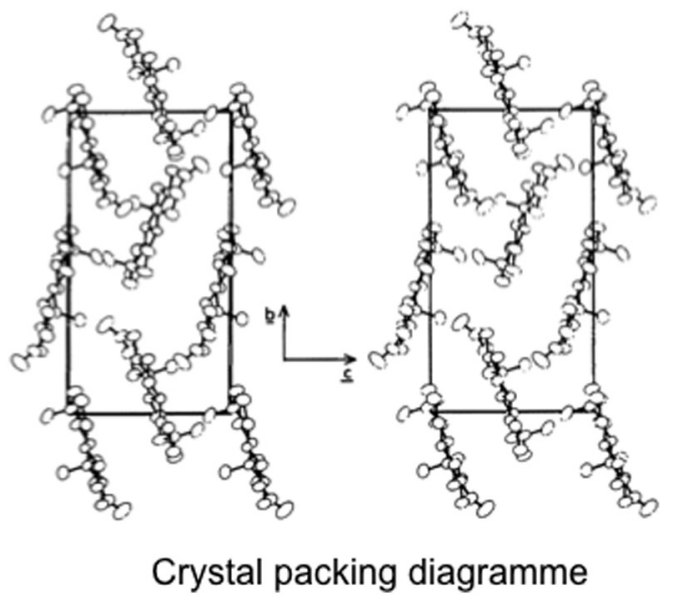

http://joe.endocrinology-journals.org DOI: 10.1530/JOE-17-0136
๑) 2017 Society for Endocrinology Printed in Great Britain

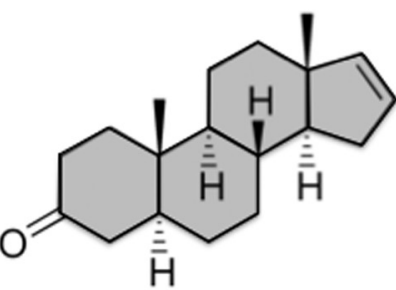

Androstenone
Figure 4

Structure of the steroidal pheromone, androstenone. (left) Stereoscopic view of the crystal packing diagram. Reprinted from Tetrahedron, vol 40, issue 16, PJ Cox \& AB Turner, Synthesis, X-ray structure and molecular mechanics studies of the boar taint steroid (5-androst-16-en-3-one), pp. 3135-3138, Copyright (1984), with permission from Elsevier. (right) Steroidal structure of androstenone deduced by Prelog et al. (1944). 
for the prize of copulating with females in estrus (Wyatt 2009). A major component of this smelly cocktail is the boar taint steroid, androstenone (Fig. 4). To humans, this steroidal pheromone 'has an unpleasant odor of perspiration' (Patterson 1968). However, to an estrous sow, a mere whiff can induce her to adopt the receptive mating stance, in readiness for copulation (Patterson 1968, Dorries et al. 1997).

\section{Summary}

- Estrus describes the vertebrate female state of maximum sexual desire and readiness for copulation.

- Estrone was the first estrus-inducing steroid to be isolated.

- Estrus and estrone are named after the Greek word for gadfly oistros.

- The gadfly features in Virgil's verse in The Georgics, as a biting, buzzing insect that incites frenzy in grazing livestock.

- Insects (arthropods) moult: ecdysis (Greek ekduo 'to take off, strip off').

- Ecdysis is stimulated by moult-inducing steroids, of which ecdysone was first to be isolated.

- Ecdysterone (potent ecdysone metabolite) has anabolic effects in vertebrates, mediated by ER.

- Estradiol (potent estrone congener) has ecdysteroidlike actions in arthropods, mediated by EcR.

- Ecdysteroids function as vertebrate sex steroid equivalents in insects.

- Ecdysteroids modify precopulatory mating behaviour in flies.

\section{Conclusion}

The roles of estrone and ecdysone in estrus and ecdysis testify to the ubiquitous impact of sterol/steroid signaling on reproductive fitness in mammals and insects. The mate-moult parallel clearly warrants a more detailed analysis than that drawn here, in the spirit of Medawar's dictum that '... 'endocrine evolution' is not an evolution of hormones but an evolution of the use to which they are put' (Medawar 1953).

\section{Declaration of interest}

The author declares that there is no conflict of interest that could be perceived as prejudicing the impartiality of this commentary.

\section{Funding}

This work did not receive any specific grant from any funding agency in the public, commercial or not-for-profit sector.

\section{Acknowledgements}

This article is framed on a lecture of the same title that I delivered at the 2016 BES annual meeting in Brighton. 2016 marked the 80th anniversary of the crystallization of estradiol (MacCorquodale et al. 1936) and the 50th anniversary of the discovery of ecdysterone (Nakanishi et al. 1966).

\section{References}

Adam NK, Danielli JF, Dodds EC, King H, Marrian GF, Parkes AS \& Rosenheim O 1933 Nomenclature of the oestrin group. Nature 132 205-206. (doi:10.1038/132205b0)

Allen E \& Doisy EA 1924 The induction of a sexually mature condition in immature females by injection of the ovarian follicular hormone. American Journal of Physiology 69 577-588. (available at: http:// ajplegacy.physiology.org/content/69/3/577)

Báthori M, Tóth N, Hunyadi A, Márki A \& Zádor E 2008 Phytoecdysteroids and anabolic-androgenic steroids - structure and effects on humans. Current Medicinal Chemistry 15 75-91. (doi:10.2174/092986708783330674)

Bloch K 1982 The structure of cholesterol and the bile acids. Trends in Biochemical Sciences 7 334-336. (doi:10.1016/0968-0004(82)90267-5)

Boulanger A \& Dura JM 2015 Nuclear receptors and Drosophila neuronal remodeling. Biochimica et Biophysica Acta 1849 187-195. (doi:10.1016/j.bbagrm.2014.05.024)

Butenandt A 1929 Über 'Progynon' ein krystallisiertes weibliches sexualhormon. Naturwissenschaften 17 879-879. (doi:10.1007/ BF01506919)

Butenandt A 1932 Chemical constitution of the follicular and testicular hormones. Nature 130 238. (doi:10.1038/130238a0)

Butenandt A \& Tschering K 1935 Über androsteron, ein krystallisiertes männliches sexualhormon. I. Isolierung und reindarstellung aus männerharn. Hoppe-Seyler's Zeitschrift für Physiologische Chemie 229 167-184.

Butenandt A \& Westphal U 1935 Zur isolierung und charaktersierung des corpus-luteum hormons. Berichte Deutsche Chemische Gesellschaft 67 1440-1442. (doi:10.1002/cber.19340670831)

Butenandt A \& Karlson P 1954 Über die isolierung eines metamorphosehormons der insekten in kristallisierter form. Zeitschrift für Naturforschung B 9 389-391.

Callow RK \& Young FG 1936 Relations between optical rotatory power and constitution in the steroids. Proceedings of the Royal Society of London: Series A, Mathematical and Physical Sciences 157 194-212. (doi:10.1098/rspa.1936.0188)

Carlisle CH \& Crowfoot D 1945 The crystal structure of cholesteryl iodide. Proceedings of the Royal Society of London: Series A, Mathematical and Physical Sciences 184 64-83. (doi:10.1098/rspa.1943.0040)

Chang ES \& Mykles DL 2011 Regulation of crustacean molting: a review and our perspectives. General and Comparative Endocrinology 172 323-330. (doi:10.1016/j.ygcen.2011.04.003)

Corner GW 1964 The early history of the oestrogenic hormones. Journal of Endocrinology $\mathbf{3 1}$ iii-xvii.

Courrier R 1924 Nouvelles recherches sur la folliculine; contribution à l'étude du passage des hormones au travers du placenta. Comptes Rendus de l'Académie des Sciences 1792192.

Cox PJ \& Turner AB 1984 Synthesis, X-ray structure and molecular mechanics studies of the boar taint steroid (5-androst-16-en-3-one). Tetrahedron 40 3135-3138. (doi:10.1016/s0040-4020(01)82442-x)

Published by Bioscientifica Ltd 
Das S 2016 Vertebrate hormones in insects: the role of estrogen in silkworm - a review. Turkish Journal of Zoology 40 297-302. (doi:10.3906/zoo-1507-37)

David K, Dingemanse E, Freud J \& Laqueur E 1935 Über krystallinisches männliches hormon aus hoden (testosteron), wirksamer als aus harn oder aus cholesterin bereitetes. Zeitschrift für physiologische Chemie 233 281-281. (doi:10.1515/bchm2.1935.233.5-6.281)

De Loof AG 2006 Ecdysteroids: the overlooked sex steroids of insects? Males: the black box. Insect Science 13 325-338. (doi:10.1111/j.17447917.2006.00101.x)

De Loof AG, Schoofs L \& Hybrechts R 2016 The endocrine system controlling sexual reproduction in animals: Part of the evolutionary ancient but well conserved immune system? General and Comparative Endocrinology 226 56-71. (doi:10.1016/j.ygcen.2015.12.016)

Dinan L 2009 The Karlson lecture. Phytoecdysteroids: what use are they? Archives of Insect Biochemistry and Physiology 72 126-141. (doi:10.1002/arch.20334)

Doisy EA 1941 The estrogenic substances. JAMA 116 501-505. (doi:10.1001/jama.1941.62820060004011)

Doisy EA, Ralls JO, Allen E \& Johnston CG 1924 The extraction and some properties of an ovarian hormone. Journal of Biological Chemistry $\mathbf{6 1}$ 711-727.

Doisy EA, Veler CD \& Thayer SA 1929 Folliculin from the urine of pregnant women. American Journal of Physiology 90 329-329.

Doisy EA, Veler CD \& Thayer S 1930 The preparation of the crystalline ovarian hormone from the urine of pregnant women. Journal of Biological Chemistry 86 499-509.

Dorries KM, Adkins-Regan E \& Halpern BP 1997 Sensitivity and behavioral responses to the pheromone androstenone are not mediated by the vomeronasal organ in domestic pigs. Brain Behavior and Evolution 49 53-62. (doi:10.1159/000112981)

Ganter GK, Desilets JB, Davis-Helm JA, Panaitiu AE, Sweezy M, Sungail J, Tan LCH, Adams AM, Fisher EA, O'Brien JRM, et al. 2012 Drosophila female precopulatory behavior is modulated by ecdysteroids. Journal of Insect Physiology 58 413-419. (doi:10.1016/j.jinsphys.2012.01.004)

Gorelick-Feldman J, Maclean D, Ilic N, Poulev A, Lila MA, Cheng D \& Raskin I 2008 Phytoecdysteroids increase protein synthesis in skeletal muscle cells. Journal of Agricultural and Food Chemistry 56 3532-3537. (doi:10.1021/jf073059z)

Hampshire F \& Horn DHS 1966 Structure of Crustecdysone, a crustacean moulting hormone. Chemical Communications 2 37-38. (doi:10.1039/ c19660000037)

Heape W 1900 The 'sexual season' of mammals and the relation of the 'pro-oestrum' to menstruation. Quarterly Journal of Microscopical Science 44 1-70.

Hillier SG 2007 Diamonds are forever: the cortisone legacy. Journal of Endocrinology 195 1-6. (doi:10.1677/JOE-07-0309)

Hodgkin DC 1972 The X-ray analysis of complicated molecules. [Nobel Lecture, December 11, 1964]. In Nobel Lectures, Chemistry 1963-1970, 71-91. Amsterdam, Netherlands: Elsevier Publishing Co.

Horn DHS, Middleton J \& Wunderllich JA 1966 Identity of the moulting hormones of insects and crustaceans. Chemical Communications $\mathbf{1 1}$ 339-341. (doi:10.1039/c19660000339)

Huber R \& Hoppe W1965 Zur Chemie des Ecdysons, VII: Die kristall- und molekülstrukturanalyse des insektenverpuppungshormons ecdyson mit der automatisierten faltmolekülmethode. Chemische Berichte 98 2403-24. (doi:10.1002/cber.19650980744)

Kaplanis JN, Robbins WE, Thompson MJ \& Baumhover AH 1969 Ecdysone analog: conversion to alpha ecdysone and 20-hydroxyecdysone by an insect. Science 166 1540-1541. (doi:10.1126/science.166.3912.1540)

Kaplanis JN, Thompson MJ, Robbins WE \& Bryce BM 1967 Insect hormones: alpha ecdysone and 20-hydroxyecdysone in bracken fern. Science 157 1436-1438. (doi:10.1126/science.157.3795.1436)
Karlson P 1995 Obituary: Professor Adolf Butenandt. The Independent Wednesday 1 February 1995. (available at: http://www.independent. co.uk/news/people/obituary-professor-adolf-butenandt-1570960. html)

Karlson P 1996 On the hormonal control of insect metamorphosis: A historical perspective. Journal of Developmental Biology 40 93-96.

Karlson P, Hoffmeister H, Hummel H, Hocks P \& Spiteller G 1965 Reaktionen des ecdysonmoleküls. Chemische Berichte 98 2394-2402. (doi:10.1002/cber.19650980743)

King DS \& Siddall JB 1966 Conversion of $\alpha$-ecdysone to $\beta$-ecdysone by crustaceans and insects. Nature 221 955-956. (doi:10.1038/221955a0)

Klyne W 1957 The Chemistry of the Steroids, p 21. London, UK: Methuen $\&$ Co.

Knauer E 1900 Die Ovarientransplantation. Experimentelle Studie. Archiv für Gynäkologie 60 524-528.

Laekeman G \& Vlietinck A 2013 Phytoecdysteroids: Phytochemistry and Pharmacological Activity. In Natural Products, pp 3827-3849. Eds KG Ramawat \& JM Mérillon. Berlin, Germany: Springer-Verlag.

Laquer E, Dingemanse E \& Kober S 1930 Crystalline 'Menformon'. Nature 125 90-90. (doi:10.1038/125090a0)

MacCorquodale DW, Thayer SA \& Doisy EA 1936 The isolation of the principal estrogenic substance of liquor folliculi. Journal of Biological Chemistry 115 435-448.

Mackenzie KR (1969) Virgil-The Georgics, Book III, pp 54-56. London, UK: The Folio Society.

Marrian GF 1930 The chemistry of oestrin: the chemical nature of crystalline preparations. Biochemical Journal 24 1021-1030. (doi:10.1042/bj0241021)

Mason HL, Meyers CS \& Kendall EC 1936 The chemistry of crystalline substances isolated from the suprarenal gland. Journal of Biological Chemistry 114 613-631.

Medawar PB 1953 Some immunological and endocrinological problems raised by the evolution of viviparity in vertebrates. In Symposia of the Society for Experimental Biology Number VII Evolution, pp 320-338. Eds R Brown \& JF Danielli. Cambridge, UK: Cambridge University Press.

Nakanishi K, Koreeda M, Sasaki S, Chang ML \& Hsu HY 1966 Insect hormones. The structure of ponasterone A, an insect-moulting hormone from the leaves of Podocarpus nakaii hay. Chemical Communications 915-917. (doi:10.1039/c19660000915)

Nijhout HF \& Callier V 2015 Developmental mechanisms of body size and wing-body scaling in insects. Annual Reviews of Entomology 60 141-156. (doi:10.1146/annurev-ento-010814-020841)

Parkes AS \& Bellerby CW 1926 Studies on internal secretions of ovary: distribution in ovary of oestrus-producing hormone. Journal of Physiology 61 562-575. (doi:10.1113/iphysiol.1926.sp002317)

Parr MK, Botrè F, Nass A, Hengevoss J, Diel P \& Wolber G 2015 Ecdysteroids: a novel class of anabolic agents? Biology of Sport 32 169-173. (doi:10.5604/20831862.1144420)

Parr MK, Zhao P, Haupt O, Ngueu ST, Hengevoss J, Fritzemeier KH, Piechotta M, Schlörer N, Muhn P \& Zheng WY et al. 2014 Estrogen receptor beta is involved in skeletal muscle hypertrophy induced by the phytoecdysteroid ecdysterone. Molecular Nutrition and Food Research 58 1861-1872. (doi:10.1002/mnfr.201300806)

Patterson RLS 1968 5 $\alpha$-androst-16-ene-3-one:- Compound responsible for taint in boar fat. Journal of the Science of Food and Agriculture 19 31-38. (doi:10.1002/jsfa.2740190107)

Prelog V, Ruzicka L \& Wieland P 1944 Uber die herstellung der beiden moschusartig riechenden $\Delta^{16}$-Androstenole-(3) und verwandter verbindungen. Helvetica Chimica Acta 27 66-71. (doi:10.1002/ jsfa.2740190107)

Reichstein T 1936 Über bestandteile der nebennieren-rind, VI. Trennungs-methoden sowie isolierung der substanzen $\mathrm{Fa}, \mathrm{H}$ und J. Helvetica Chimica Acta 19 1107-1126. (doi:10.1002/ hlca.193601901149) http://joe.endocrinology-journals.org

DOI: $10.1530 / \mathrm{JOE}-17-0136$
() 2017 Society for Endocrinology Printed in Great Britain
Published by Bioscientifica Ltd. 
Ruzicka L \& Wettstein A 1935 Sexualhormone V. Künstliche herstellung des männlichen sexualhormons trans-dehydro-androsteron und des androsten-3,17-dions. Helvetica Chimica Acta 18 986-994. (doi:10.1002/hlca.193501801132)

Schwedes CC \& Carney GE 2012 Ecdysone signaling in adult Drosophila melanogaster. Journal of Insect Physiology 58 293-302. (doi:10.1016/j. jinsphys.2012.01.013)

Simpson E \& Santen RJ 2015 Celebrating 75 years of oestradiol. Journal of Molecular Endocrinology 55 T1-T20. (doi:10.1530/JME-15-0128)

Simpson SA, Tait JF, Wettstein A, Neher R, Von Euw J \& Reichstein T 1953 Isolation from the adrenals of a new crystalline hormone with especially high effectiveness on mineral metabolism. Experientia 9 333-335. (doi:10.1007/BF02155834)

Sláma K \& Lafont R 1995 Insect hormones - ecdysteroids; their presence and actions in vertebrates. European Journal of Entomology 92 355-377.

Stockard CR \& Papanicolaou GN 1917 The existence of a typical oestrous cycle in the guinea-pig - with a study of its histological and physiological changes. American Journal of Anatomy 22 225-283. (doi:10.1002/aja.1000220204)

Swetha CH, Girish BP \& Reddy PS 2016 Elucidation of the role of estradiol and progesterone in regulating reproduction in the edible crab, Orziothelphusa senex senex. RSC Advances 6 24959-24967. (doi:10.1039/C5RA23637A)

Swevers L, Lambert JGD \& De Loof A 1991 Synthesis and metabolism of vertebrate-type steroids by tissues of insects: a critical evaluation. Experientia 47 687-698. (doi:10.1007/BF01958817)

Tarkowská D \& Strnad M 2016 Plant ecdysteroids: plant sterols with intriguing distributions, biological effects and relations to plant hormones. Planta 244 545-555. (doi:10.1007/s00425-016-2561-z)

Veler CD, Thayer S \& Doisy EA 1930 The preparation of the crystalline follicular ovarian hormone: theelin. Journal of Biological Chemistry $\mathbf{8 7}$ $357-371$.

Wyatt TD 2009 Fifty years of pheromones. Nature 457 262-263. (doi:10.1038/457262a)

Received in final form 31 March 2017

Accepted 6 April 2017

Accepted Preprint published online 6 April 2017
๑) 2017 Society for Endocrinology Printed in Great Britain
Published by Bioscientifica Ltd. 